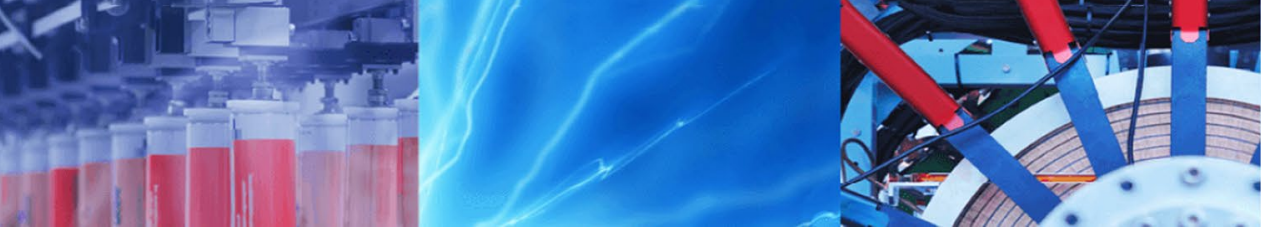

Research Article

\title{
Screening of untreated municipal solid waste incineration fly ash for use in cement-based materials: chemical and physical properties
}

\author{
Benjamin A. R. Ebert ${ }^{1}$ (D) Britt-Marie Steenari $^{2}$ (D) $\cdot$ Mette R. Geiker $^{3}$ (D) Gunvor M. Kirkelund ${ }^{1}$ (D)
}

Received: 12 October 2019 / Accepted: 26 March 2020 / Published online: 3 April 2020

(c) Springer Nature Switzerland AG 2020

\begin{abstract}
The environmental impact during concrete manufacturing can be reduced by using less cement or using types of cement with high amounts of secondary cementitious materials (SCMs) and fillers. Fly ash from municipal solid waste incineration (MSWI) is an unused material, which could potentially be used as an SCM or filler. The applicability of MSWI fly ash samples in cement-based materials was investigated through an indirect determination based on the chemical composition, toxic metal content and particle size distribution of the samples. Furthermore, how the samples compared to each other and how representative the samples were for MSWI fly ash, in general, were investigated by multivariate modelling. MSWI fly ash samples were obtained from Denmark, Sweden and Greenland. Comparing the chemical composition of the MSWI fly ash samples with the chemical requirements for coal fly ash to be used in concrete, specified in EN 450-1 2012, indicated a low potential as SCMs. Additionally, the MSWI fly ash contained and leached more toxic metals than the allowed limits. The particle size distributions were larger than cement and indicated limited potential as filler. A principal component analysis showed that the obtained samples were chemically different materials compared to each other and would have different effects if used in cement-based materials. Additionally, the samples from Denmark were unrepresentative of MSWI fly ash, while the Greenlandic and Swedish samples were comparable to previously studied MSWI fly ash samples.
\end{abstract}

Keywords Screening $\cdot$ Characterization $\cdot$ MSWI fly ash $\cdot$ Cement $\cdot$ Multivariate modelling

\section{Introduction}

Construction of new buildings and infrastructure consume large quantities of humanmade goods and raw materials, greatly impacting the environment and the sustainability of the construction industry. In 2016, the production of cement contributed to $8 \%$ of the global anthropogenic $\mathrm{CO}_{2}$ emissions [1].

The environmental impact related to construction with cementitious materials, e.g. concrete, can be reduced by using less cement, and replacing Portland cement clinker with secondary cementitious materials (SCMs) [2] or fillers. However, limited availability of traditionally used SCMs such as ground granulated blast furnace slag and fly ash from coal incineration calls for the identification of new resources [3].

Several countries have in the past decades introduced changes to their municipal solid waste disposal, such as increased material recycling from the waste and waste incineration. However, incineration of municipal solid waste results in several by-products classified as hazardous materials [4]. It has been proposed that MSWI fly ash from waste incineration could be used in concrete as an SCM [5]. The high pH in Portland cement-based materials results in chemical binding of the toxic metals, reducing short term leaching [6]. However, later reduced $\mathrm{pH}$ due

\footnotetext{
$\triangle$ Benjamin A. R. Ebert, bareb@byg.dtu.dk|'Department of Civil Engineering, Technical University of Denmark, Kgs. Lyngby, Denmark. ${ }^{2}$ Chemistry and Chemical Engineering, Chalmers University of Technology, Gothenburg, Sweden. ${ }^{3}$ Department of Structural Engineering, Norwegian University of Science and Technology, Trondheim, Norway.
} 
to, e.g. carbonation is likely to cause a release of the toxic metals.

Previous research on the utilisation of MSWI fly ash has evaluated the potential of the ashes as SCMs through direct methods, analysing the properties of cement-based materials made with MSWI fly ash [7-9]. The present study aimed at evaluating if samples of MSWI fly ash could be used as SCMs or filler in cement-based materials through an indirect determination. The indirect determination was performed by comparing the chemical properties of the samples with the chemical requirements in EN 450-1 2012 [10], evaluating the toxic metal content and by analysing the samples potential as filler materials, based on the particle size requirements presented by Moosberg-Bustnes et al. [11] and Scrivener et al. [12]. Furthermore, the present study evaluated how the samples compared to each other and previously studied MSWI fly ash samples based on their oxide and toxic metal content. Moreover, the influence of the type of furnace and flue gas filter used during waste incineration on the oxide and toxic metal content was evaluated. A principal component analysis (PCA) was used for this. A PCA is a multivariate statistical method that visualises the differences and similarities in large data sets [13]. Researchers have previously used PCA and other multivariate statistical methods when studying clustering trends and the most important characterisation properties in e.g. harbour sediments [13] and biomass ash [14, 15].

\section{Methodology}

\subsection{Materials}

Five MSWI fly ash samples were obtained from commercial MSW incineration heat and power plants. Two samples, designated Arc-Fa1 and Arc-Fa2, were obtained from Amager Bakke, Denmark, in early 2018 and late 2018 respectively. Two samples were collected from the incinerator in Nuuk, Greenland, designated Nuuk-Fa1 and Nuuk-Fa2, in 2017 and 2018 respectively. The final ash sample was obtained from Ryaverket in Sweden, designated
Rya-Fa, in mid-2018. The five MSWI fly ash samples were sampled on-site by the operators. Information about the three incinerators is included in Table 1. The fly ash samples from Amager Bakke and Nuuk were extracted before any flue gas treatment, while the sample Rya-Fa was extracted after flue gas treatment with lime and active carbon.

\subsection{Characterisation methods}

The samples included in the evaluation were dried at $50^{\circ} \mathrm{C}$. Each analysis was made in triplicate, apart from the XRF and XRD analyses that were performed once.

\subsubsection{Particle size distribution}

The particle size distributions of the five MSWI fly ash samples were measured with a Malvern Mastersizer 2000 particle size analyser. The measurements were performed in a dry state, instead of as a wet slurry. CEM I $52.5 \mathrm{~N}$ (MS/ $\mathrm{LA} / \leq 2$ ) cement with a bulk and absolute density of 1.1 and $3.2 \mathrm{~g} / \mathrm{cm}^{3}$ was used for comparison between cement and the five MSWI fly ash samples. A Malvern Mastersizer 2000 determines the particle size distribution based on light scattering from spherical particles using Mie Theory [16].

\subsubsection{Loss on ignition}

Loss on ignition (LOI) was measured as the mass loss at $950^{\circ} \mathrm{C}$ using a muffle furnace, equipped with temperature controls. Five gram of ash was ignited, in uncovered crucibles for $24 \mathrm{~h}$, and subsequently cooled in a desiccator, ensuring that constant sample mass had been achieved.

\subsection{3 $\mathrm{pH}$ and conductivity}

The $\mathrm{pH}$ and conductivity of the ashes were measured on samples suspended in distilled water. Plastic bottles containing $5 \mathrm{~g}$ of ash and $12.5 \mathrm{ml}$ distilled water (L/S 2.5) were shaken for an hour at $195 \mathrm{rpm}$. The $\mathrm{pH}$ and conductivity
Table 1 Average operating conditions of incineration plants during sampling

\begin{tabular}{llll}
\hline & Amager Bakke & Nuuk incineration & Ryaverket \\
\hline Furnace & Grate fired & Grate fired & Fluidised bed \\
Incineration temp. $\left({ }^{\circ} \mathrm{C}\right)$ & 1025 & 1064 & 900 \\
Waste type & Household/industrial & Household/construction & Household/industrial \\
Boiler ash separation & Gravitation & Gravitation/cyclone & Gravitation/cyclone \\
Flue gas filter type & Electrostatic & Electrostatic & Textile \\
Incineration capacity (ton/day) & 1680 & 40 & 300 \\
Fly ash (ton/day) & 14.8 & 0.3 & 8.9 \\
Bottom ash (ton/day) & 237 & 4.7 & 17.8 \\
\hline
\end{tabular}


were afterwards measured with a Radiometer analytical electrode and conductivity meter, respectively.

\subsubsection{Water-soluble fraction}

The weight percentage of the water-soluble fraction was measured at L/S 5 after three consecutive washings. The procedure used was the same as the L:S $3 \times 5$ washing procedure described in [17] by Chen et al. A $100 \mathrm{~g}$ of ash was mixed with $500 \mathrm{ml}$ distilled water in an Erlenmeyer flask and shaken manually. The liquid phase was decanted through a Frisenette type 1125 filter, repeating for each wash. The entire sample was filtered and dried at $50^{\circ} \mathrm{C}$, after the third washing until a constant mass had been achieved.

\subsubsection{Water-soluble anion content and batch leaching}

The content of water-soluble anions was measured with Ion Chromatography (IC). Ten gram of ash was mixed with $25 \mathrm{ml}$ distilled water (L/S 2.5) in $50 \mathrm{ml}$ bottles and shaken for $12 \mathrm{~h}$ at $195 \mathrm{rpm}$. The liquid phase was extracted with a $0.45 \mu \mathrm{m}$ filter syringe, and the content of $\mathrm{Cl}^{-}$and $\mathrm{SO}_{4}{ }^{2-}$ measured. A batch leaching test was performed to determine the leaching of $\mathrm{Cd}, \mathrm{Cr}, \mathrm{Cu}, \mathrm{Pb}$ and $\mathrm{Zn}$ from the five MSWI fly ash samples as well as their content of watersoluble $\mathrm{Ca}, \mathrm{Na}$ and $\mathrm{K}$. The test was performed by mixing $40 \mathrm{~g}$ of ash with $80 \mathrm{ml}$ distilled water (L/S 2). The mixture was shaken for $24 \mathrm{~h}$ at $195 \mathrm{rpm}$ and then filtered using $0.45 \mu \mathrm{m}$ syringe filters. The leached elements were measured using Inductively Coupled Plasma-Optical Emission Spectrometry (ICP-OES). The batch leaching test was performed according to EN 12457-1 [18].

\subsubsection{Element content analysis}

The elemental content of the five MSWI fly ash samples was determined using $\mathrm{X}$-ray fluorescence (XRF) and ICP$\mathrm{OES}$ analysis. The elements analysed with XRF were $\mathrm{Si}, \mathrm{Al}$, $\mathrm{Fe}, \mathrm{Ca}, \mathrm{Mg}, \mathrm{Na}, \mathrm{K}, \mathrm{S}, \mathrm{Cl}$ and $\mathrm{P}$. The analysis was performed by an external laboratory using a SPECTRO Gmbh X-LAB 2000 with a Pd-tube on ash samples ground to a particle size below $200 \mu \mathrm{m}$. Based on the XRF analysis, the equivalent content of oxides was calculated for comparison with EN 450-1 2012 [10]. The elements analysed with ICP-OES were $\mathrm{Cd}, \mathrm{Cr}, \mathrm{Cu}, \mathrm{Pb}$ and $\mathrm{Zn}$. Samples for ICP-OES were prepared following the specifications of Danish Standard DS259 [19]. One gram of MSWI fly ash was mixed with $20 \mathrm{ml} 7.3 \mathrm{M}$ $\mathrm{HNO}_{3}$ and heated at $120^{\circ} \mathrm{C}$ and $200 \mathrm{kPa}$ for $30 \mathrm{~min}$. The liquid was then vacuum filtered through a $45-\mu \mathrm{m}$ filter and diluted to $100 \mathrm{ml}$ with distilled water and analysed with ICP-OES. The total content of $\mathrm{Cd}, \mathrm{Cr}, \mathrm{Cu}, \mathrm{Pb}$ and $\mathrm{Zn}$ in the CEM I cement used during particle size measurements were analysed as well.

\subsubsection{X-ray diffraction}

X-ray diffraction (XRD) analysis was performed using a PanAlytical X'pert PRO $\Theta-\Theta$ System, with a target metal anode made from $\mathrm{Cu}$. Intensities were measured from $0^{\circ}$ to $90^{\circ}$. Samples were pulverised in a mortar to increase the fineness and backloaded into sample holders. Peak and phase identification was performed using the ICDD PDF4 database. The detection limit of the XRD analysis was $2 \mathrm{wt} \%$.

\subsubsection{Thermogravimetric analysis}

Thermogravimetric analysis (TGA) was performed using a NETZSCH STA 449 F3 Jupiter, fitted with a silicon carbide furnace and top-loading. Aluminium oxide sample holders were filled with approximately $35 \mathrm{mg}$ of ash and heated to $29^{\circ} \mathrm{C}$. After $10 \mathrm{~min}$ at $29^{\circ} \mathrm{C}$, the temperature was raised to $900^{\circ} \mathrm{C}$, at $10^{\circ} \mathrm{C} / \mathrm{min}$. Nitrogen was used as a purge gas, at a constant flow of $50 \mathrm{ml} / \mathrm{min}$. The results of the analysis are included as the first derivative of the thermogravimetric mass loss (DTG).

\subsection{Principal component analysis (PCA)}

A principal component analysis (PCA) deals with possible collinearity between variables in a large data set [20]. Traditional statistical analysis, e.g. multiple regression analysis assumes that the variables of an observation are independent, potentially leading to biased results if the variables are correlated. A PCA can visualise the differences and similarities between observations by determining the principal components of the observations. A principal component is a vector that best explains the variance between observations. A PCA contains several principal components, each perpendicular to the previous. The 1st principal component accounts for the majority of the observations, while each subsequent principal component accounts for less. In this study, observations are referred to as the MSWI fly ash samples, variables as oxide composition and toxic metal content. Furnace and filter types are secondary input that characterises the samples.

The results of a PCA is given as loadings and scores. The principal component loadings are the weight of significance of the variables in the principal component vector and indicate if there is a positive or negative correlation between the variables. The principal component scores provide information on the individual observations with regard to their loadings. The scores are coordinates on the vector from the perpendicular projection of all points in the dataset. An observation's principal component score is 
a linear combination of the observation's projected points, where the loadings are the weight of the projection. Each principal component has a series of loadings, equal to the number of variables, and scores equal to the number of observations. Combined plots of the loadings and the scores for two principal components provide information on how variables and observations correlate. Furthermore, similar observations (in the original dataset) will have similar scores.

\subsubsection{Data compilation}

Experimental data for the PCA covered MSWI fly ash samples from both the present study and literature [21-40]. The dataset for the PCA consisted of 51 MSWI fly ash samples and a coal fly ash, from Greenland, Europe and Asia. An MSWI fly ash sample was only included if the type of furnace and flue gas filter device of the incineration plant as well as the country of origin were specified in the reference. The composition of the incineration plant fuel was not considered due to inadequate reporting of the fuel composition in the literature.

The variables in the $\mathrm{PCA}$ were $\mathrm{Al}_{2} \mathrm{O}_{3}, \mathrm{Fe}_{2} \mathrm{O}_{3}, \mathrm{SiO}_{2}, \mathrm{CaO}$, $\mathrm{MgO}, \mathrm{Na}_{2} \mathrm{O}, \mathrm{K}_{2} \mathrm{O}, \mathrm{SO}_{3}, \mathrm{Cl}, \mathrm{Pb}, \mathrm{Zn}, \mathrm{Cu}, \mathrm{Cr}$ and $\mathrm{Cd}$. Several references $[22,25,27,30,31,33,36,37,39]$ reported elemental content instead of oxide content. The corresponding oxide content was calculated based on the reported elemental content. The furnace type of the included incineration plants was categorised as either a grate furnace or fluidised bed furnace. The flue gas filter was categorised as either an electrostatic precipitator (ESP) or a fabric filter.
The PCA included, in addition to the samples from ESP or fabric filters, a cyclone and a boiler ash sample.

The PCA was performed using the statistical program Simca 14.1 by Sartorius Stedim Biotech. The PCA used standardised residual with $R^{2}$ specified as explained variance, as well as scaled and centred coefficients. Crossvalidation was used when fitting with 7 cross-validation groups. A maximum of 200 iterations was used together with a missing data tolerance $\%(\operatorname{Var})$ of 5 . The confidence level on parameters was set to $95 \%$. The $1 \mathrm{st}, 2 \mathrm{nd}$ and 3rd principal components were used in the analysis and accounted for $67 \%$ of the variation in the dataset. The components each accounted for 34,22 and $12 \%$ of the variance, respectively. The $Q^{2}$ of each component were 0.12 , 0.13 and -0.07 , respectively.

Included in the analysis were the oxide composition and toxic metal content of a coal fly ash that fulfils the specifications of EN 450-1 2012 [10]. The oxide and toxic metal content of the coal fly ash were measured using the previously mentioned methods. The inclusion of the coal fly ash as an outlier in the PCA did not change the interpretation of the PCA results.

\section{Results}

\subsection{Chemical properties}

The calculated contents of oxides are shown in Table 2, together with the chloride content and LOI for the five MSWI fly ash samples. Included in Table 2 are the
Table 2 Calculated content of oxides ( $w t \%)$ as well as $\mathrm{Cl}$ (wt\%) and LOI (wt\%)

\begin{tabular}{lccccclll}
\hline & Arc-Fa1 & Arc-Fa2 & Nuuk-Fa1 & Nuuk-Fa2 & Rya-Fa & EN 450-1 & MSWI [20-39] & Coal [42] \\
\hline $\mathrm{SiO}_{2}$ & 4.9 & 4.5 & 4.7 & 5.6 & 6.0 & $\geq 25$ & $2.4-33.4$ & $14.8-56.7$ \\
$\mathrm{Al}_{2} \mathrm{O}_{3}$ & 2.3 & 1.5 & 4.0 & 4.3 & 4.5 & - & $0.5-15.4$ & $3.4-38.4$ \\
$\mathrm{Fe}_{2} \mathrm{O}_{3}$ & 1.1 & 1.0 & 0.7 & 0.8 & 1.7 & - & $0.3-9.1$ & $0.86-9.7$ \\
$\mathrm{~S}_{\left(\mathrm{SiO}_{2},\right.}$ & 8.3 & 7.0 & 9.4 & 10.7 & 12.2 & $\geq 70$ & $4.0-56.0$ & $19.1-97.6$ \\
$\mathrm{Al}_{2} \mathrm{O}_{3}$, & & & & & & & & \\
$\left.\mathrm{Fe}_{2} \mathrm{O}_{3}\right)$ & & & & & & & & \\
$\mathrm{CaO}$ & 21.0 & 13.4 & 33.6 & 40.6 & 40.6 & $\leq 1.5 / 10^{*}$ & $12.6-57.4$ & $0.5-54.1$ \\
$\mathrm{MgO}$ & 0.8 & 0.7 & 0.9 & 1.3 & 1.7 & $\leq 4.0$ & $0.1-8.1$ & $0.2-9.1$ \\
$\mathrm{SO}_{3}$ & 22.5 & 35.0 & 7.7 & 8.2 & 8.7 & $\leq 3.0$ & $2.2-20.5$ & $0.2-22.1$ \\
$\mathrm{~K}_{2} \mathrm{O}$ & 13.3 & 14.5 & 10.7 & 11.3 & 2.4 & - & $0.6-21.7$ & $0.2-4.9$ \\
$\mathrm{Na}_{2} \mathrm{O}$ & 17.5 & 9.2 & 21.6 & 21.6 & 6.2 & - & $2.0-24.9$ & $0.04-1.2$ \\
$\mathrm{Na}_{2} \mathrm{O}_{\text {eq }}$ & 26.3 & 18.7 & 28.6 & 29.0 & 7.8 & $\leq 5.0$ & $1.5-38.6$ & $0.2-4.5$ \\
$\mathrm{P}_{2} \mathrm{O}_{5}$ & 1.4 & 3.0 & 1.3 & 1.8 & 1.7 & $\leq 5.0$ & $0.2-3.6$ & $0.02-0.5$ \\
$\mathrm{Cl}$ & 8.9 & 3.0 & 20.0 & 22.0 & 12.0 & $\leq 0.1$ & $3.1-42.0$ & - \\
$\mathrm{LOI}$ & 3.8 & 10.7 & 31.2 & 9.2 & 21.4 & $\leq 9.0^{* *}$ & - & $1.8-8.2$ \\
\hline
\end{tabular}

Included are the requirements specified in En 450-1 as well as the composition of MSWI and Coal fly ash seen in the literature

*Free $\mathrm{CaO}$ limit/Reactive $\mathrm{CaO}$ limit

${ }^{* *}$ Category $\mathrm{C}$ 
requirements specified in EN 450-1 2012 [10] for using coal fly ash in cement-based materials, as well as the results found in other studies for MSWI fly ash [20-39] and coal fly ash [42]. The five MSWI fly ash samples evaluated in the present study only fulfilled the chemical requirements specified in EN 450-1 2012 [10], for $\mathrm{MgO}$ and $\mathrm{P}_{2} \mathrm{O}_{5}$. The five MSWI fly ash samples contained less $\mathrm{SiO}_{2}$ than the limit of at least $25 \mathrm{wt} \%$ reactive $\mathrm{SiO}_{2}$, regardless if the determined $\mathrm{SiO}_{2}$ content is reactive or not, and had a combined content of $\mathrm{SiO}_{2}, \mathrm{Fe}_{2} \mathrm{O}_{3}$ and $\mathrm{Al}_{2} \mathrm{O}_{3}$ of approximately one-seventh the lower limit of $70 \mathrm{wt} \%$. The $\mathrm{SiO}_{2}$ content was less than the range indicated for coal fly ash [42] and was in the low range of what was observed for MSWI fly ash [20-39]. The $\mathrm{Al}_{2} \mathrm{O}_{3}$ and $\mathrm{Fe}_{2} \mathrm{O}_{3}$ content were within the range of both MSWI and coal fly ash, with the exception of the Arc samples that contained less $\mathrm{Al}_{2} \mathrm{O}_{3}$ and the Nuuk samples that contained less $\mathrm{Fe}_{2} \mathrm{O}_{3}$ than the range for coal fly ash [42]. The content of $\mathrm{Na}_{2} \mathrm{O}_{\text {eq, }}$ in the five fly ash samples, was within the range of MSWI fly ash [20-39]. However, the range for coal fly ash [42] was exceeded. The samples Arc-Fa1 and Arc-Fa2 both had low amounts of $\mathrm{Cl}$ and high amounts of $\mathrm{SO}_{3}$, exceeding the $\mathrm{SO}_{3}$ range for both MSWI and coal fly ash, while Nuuk-Fa1 and Nuuk-Fa2 contained high amounts of $\mathrm{Cl}$ and low amounts of $\mathrm{SO}_{3}$. Compared to the Arc and Nuuk samples, Rya-Fa contained low amounts of both $\mathrm{Cl}$ and $\mathrm{SO}_{3}$.

Large variations in LOI was observed for the five MSWI fly ash samples, between 3.8 and $31.2 \mathrm{wt} \%$. Variations between samples obtained from the same incineration plant could be observed as well, with the LOI increasing by $6.9 \mathrm{wt} \%$ between Arc-Fa 1 and Arc-Fa2 and decreasing by 22 wt\% between Nuuk-Fa1 and Nuuk-Fa2. EN 450-1 2012 [10] specifies a maximum LOI limit of $9.0 \mathrm{wt} \%$, all but Arc-Fa1 exceeded the limit as well as the range observed for coal fly ash.

The DTG curves of the five MSWI fly ash samples are shown in Fig. 1. The most extensive mass loss occurred between 500 and $700^{\circ} \mathrm{C}$. A second extensive mass loss was observed after $700^{\circ} \mathrm{C}$. According to Du et al. [43] carbonates in MSWI fly ash decompose between 402 and $725^{\circ} \mathrm{C}$, while mass loss observed between 725 and $1030^{\circ} \mathrm{C}$ corresponds to the decomposition of sulphates. However, Galan et al. [44] suggest that $\mathrm{CaCO}_{3}$ decomposes between 700 and $1000^{\circ} \mathrm{C}$ in an $\mathrm{N}_{2}$ atmosphere. The reduced decomposition temperature of $\mathrm{CaCO} 3$ could be caused by $\mathrm{NaCl}$, as suggested by Wieczorek-ciurowa et al. [45]. The mass loss observed between 500 and $700{ }^{\circ} \mathrm{C}$ in the present study could, therefore, indicate the presence of $\mathrm{CaCO}_{3}$ for NuukFa1, Nuuk-Fa2, Rya-Fa and Arc-Fa1. The second mass loss could be the result of sulphate phases decomposing. Several small mass losses could be observed between 0 and $500{ }^{\circ} \mathrm{C}$, indicating potential loss of mass from several different phases, or the sequential decomposition of a single phase. Additionally, the samples Nuuk-Fa1 and Nuuk-Fa2 had similar DTG curves, while Arc-Fa1 and Arc-Fa2 had different peaks, indicating similarities and differences between the Nuuk and Arc samples respectively.

The XRD patterns of the five MSWI fly ash samples are shown in Fig. 2. Peaks for $\mathrm{CaSO}_{4}$ and $\mathrm{NaCl}$ were found in all five fly ash samples, while peaks for $\mathrm{CaCO}_{3}$ and $\mathrm{KCl}$

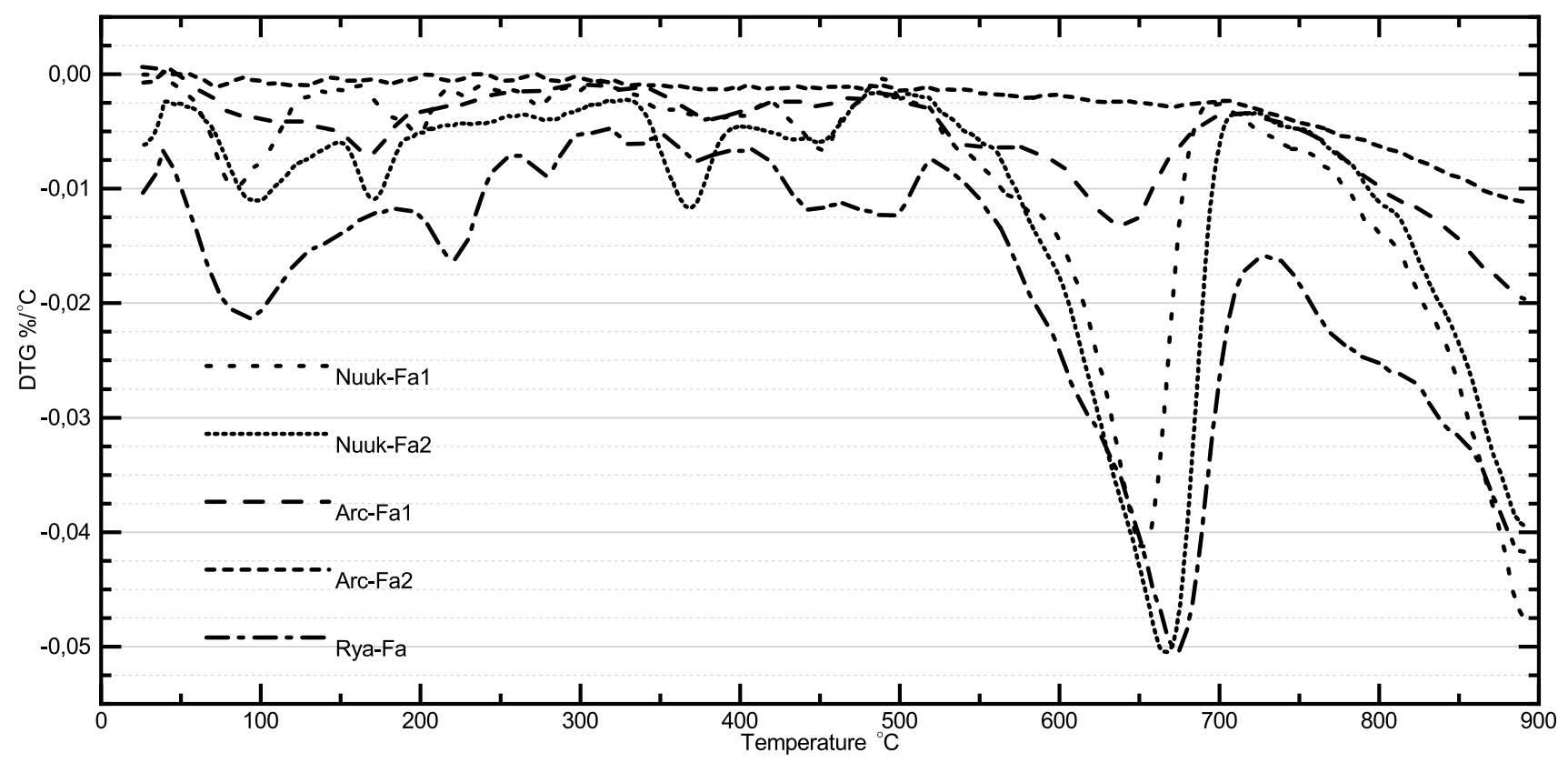

Fig. 1 DTG curves of the five MSWI fly ash samples 


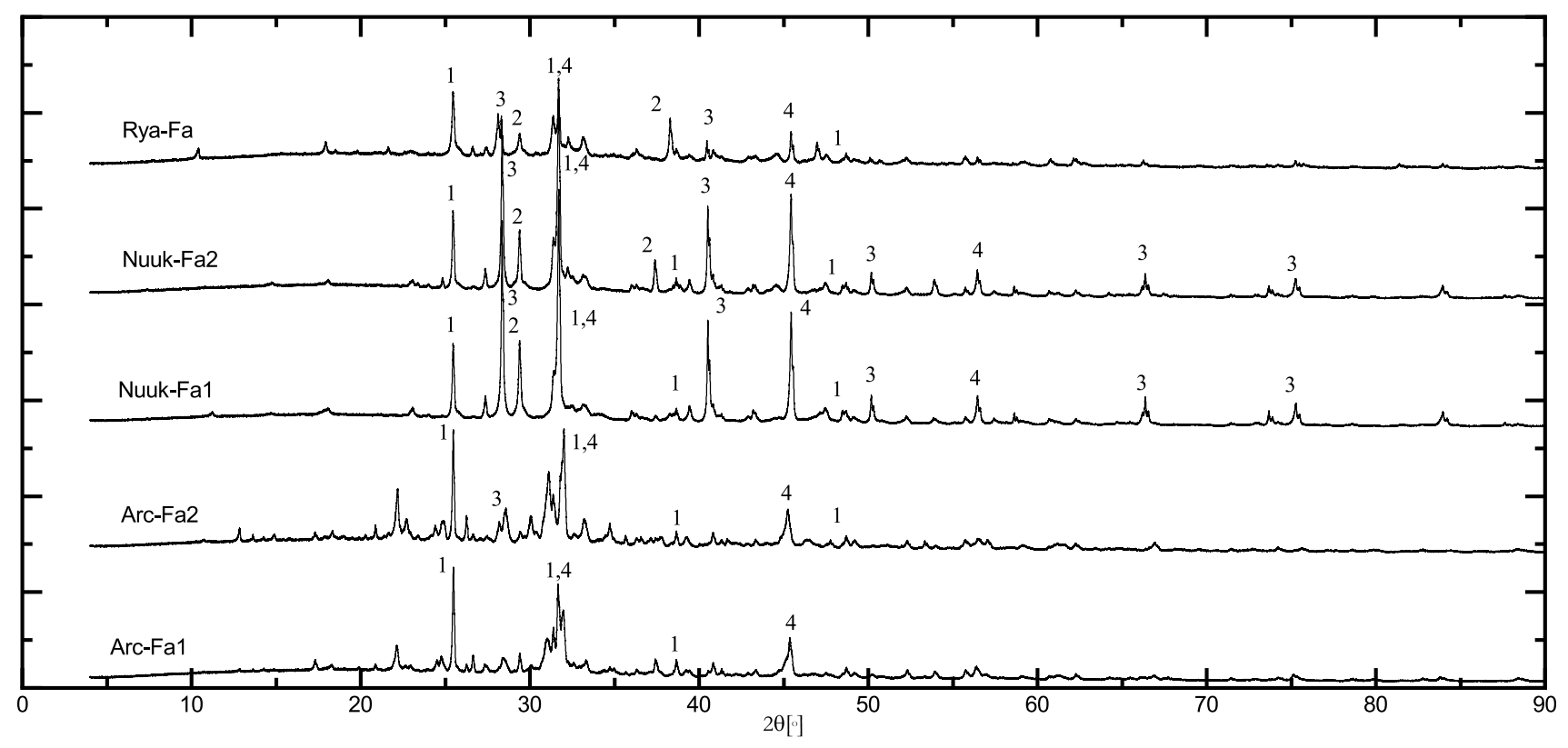

Fig. 2 X-ray diffractograms of the five MSWI fly ash samples. $1=\mathrm{CaSO}_{4}, 2=\mathrm{CaCO}_{3}, 3=\mathrm{KCl}$ and $4=\mathrm{NaCl}$

were present in Nuuk-Fa1, Nuuk-Fa2 and Rya-Fa. The two Nuuk samples appeared to have similar diffraction patterns, diverging from each other in peaks for $\mathrm{CaCO}_{3}$. The samples Arc-Fa1 and Arc-Fa2 showed several peak differences, between $20^{\circ}$ and $35^{\circ}$, indicating differences in composition between the samples. The sample Arc-Fa2 could potentially contain several different sulphur compounds such as $\mathrm{KNaSO}_{4}$ and $\mathrm{Mg}_{2} \mathrm{NaOH}\left(\mathrm{SO}_{3}\right)_{2} \cdot \mathrm{H}_{2} \mathrm{O}$, not observed in the other ash samples.

The maximum limit for free and reactive $\mathrm{CaO}$ was exceeded in all five MSWI fly ash samples, see Table 3. However, as indicated by the TGA and XRD analysis, the $\mathrm{Ca}$ in the five MSWI fly ash samples can be present as $\mathrm{CaCO}_{3}$ or $\mathrm{CaSO}_{4}$.

Table 3 contains the measured $\mathrm{pH}$, conductivity, water solubility and water-soluble content of the five MSWI fly ash samples. Four samples were alkaline, with a $\mathrm{pH}$ between 11 and 12, and electrical conductivities between 90 and $150 \mathrm{mS} / \mathrm{cm}^{2}$. Pedersen et al. [46] measured the
$\mathrm{pH}$ of two MSWI fly ash samples from different incineration plants and determined their $\mathrm{pH}$ to be 10.8 and 12.2, respectively. The $\mathrm{pH}$ of Arc-Fa2 differs from these results with a $\mathrm{pH}$ of 6.5 , indicating that MSWI fly ash can have a neutral $\mathrm{pH}$ as well as alkaline $\mathrm{pH}$. The lower $\mathrm{pH}$ of ArcFa2 could be a result of its high ratio of sulphur to other elements.

High solubility in water was observed for the five MSWI fly ash samples, varying between approximately $28 \mathrm{wt} \%$ and $56 \mathrm{wt} \%$. The measured solubilities indicated that $\mathrm{Cl}^{-}$was present in soluble form, matching the amounts measured with XRF, except for Rya-Fa, where the soluble $\mathrm{Cl}^{-}$was $5 \mathrm{wt} \%$ higher, indicating that the measured $\mathrm{Cl}$ is higher in Rya-Fa than measured with XRF. The soluble $\mathrm{Na}^{+}$content measured in Arc-Fa2 did not match the XRF analysis either. The samples Arc-Fa1 and Arc-Fa2 contained a higher content of soluble $\mathrm{SO}_{4}{ }^{2-}$ than the other samples. In comparison, Rya-Fa had a higher content of soluble $\mathrm{Ca}^{2+}$, matching the results of the
Table 3 Measured $\mathrm{pH}$, conductivity, water solubility and content of water-soluble $\mathrm{Cl}^{-}, \mathrm{SO}_{4}{ }^{2-}$ and $\mathrm{NO}_{3}{ }^{-}$anions and water-soluble $\mathrm{Ca}, \mathrm{Na}$ and $\mathrm{K}$ of the five MSWI fly ash samples

\begin{tabular}{lccccr}
\hline & \multicolumn{1}{c}{ Arc-Fa1 } & \multicolumn{1}{c}{ Arc-Fa2 } & Nuuk-Fa1 & Nuuk-Fa2 & \multicolumn{1}{c}{ Rya-Fa } \\
\hline $\mathrm{pH}(-)$ & $12.0 \pm 0.1$ & $6.5 \pm 0.0$ & $11.6 \pm 0.0$ & $11.9 \pm 0.0$ & $11.5 \pm 0.0$ \\
Conductivity (mS/cm) & $114 \pm 4$ & $94.7 \pm 1.3$ & $150 \pm 21$ & $147 \pm 5$ & $93.5 \pm 1.2$ \\
Water Solubility (wt\%) & $39.4 \pm 0.5$ & $55.7 \pm 2.3$ & $42.4 \pm 1.3$ & $38.0 \pm 0.6$ & $27.7 \pm 0.9$ \\
$\mathrm{Cl}^{-}$(wt\%) & $8.1 \pm 0.1$ & $2.3 \pm 0.2$ & $19.1 \pm 0.9$ & $22.2 \pm 0.4$ & $17.6 \pm 0.5$ \\
$\mathrm{SO}_{4}{ }^{2-}$ (wt\%) & $7.5 \pm 0.0$ & $21.1 \pm 0.6$ & $0.8 \pm 0.0$ & $0.6 \pm 0.0$ & $0.2 \pm 0.0$ \\
$\mathrm{Ca}^{2+}$ (wt\%) & $0.1 \pm 0.0$ & $0.1 \pm 0.0$ & $0.7 \pm 0.1$ & $1.9 \pm 0.1$ & $6.0 \pm 0.9$ \\
$\mathrm{Na}^{+}$(wt\%) & $7.7 \pm 0.1$ & $10.4 \pm 0.2$ & $6.3 \pm 1.1$ & $7.6 \pm 0.2$ & $1.6 \pm 0.1$ \\
$\mathrm{~K}^{+}($wt\%) & $3.9 \pm 0.1$ & $3.1 \pm 0.1$ & $5.6 \pm 1.0$ & $6.8 \pm 0.2$ & $1.3 \pm 0.1$ \\
\hline
\end{tabular}


XRF analysis where the samples from Arc had the highest content of Sulphur, and Rya-Fa the highest content of Calcium. The samples Nuuk-Fa1 and Nuuk Fa2 had similar water solubilities, while the sample Arc-Fa2 had approximately $16 \mathrm{wt} \%$ more soluble mass than Arc-Fa1.

The total content of toxic metals is shown in Table 4, together with the results of the batch leaching test, the total content measured in a CEM I cement and in previously studied MSWI fly ash samples [21-40]. The studied MSWI fly ashes were all characterised as having low amounts of $\mathrm{Cd}$ and $\mathrm{Cr}$ compared to $\mathrm{Cu}, \mathrm{Pb}$ and $\mathrm{Zn}$. The sample from the fluidised bed incinerator contained low total concentrations of $\mathrm{Cd}, \mathrm{Cr}$ and $\mathrm{Zn}$, and a higher total concentration of $\mathrm{Cu}$ compared to the other samples. In contrast, the samples from the large grate fired incinerator contained higher total concentrations of $\mathrm{Pb}$ and $\mathrm{Zn}$. Arc-Fa2 differed further from Arc-Fa1 with an approximately twice as high total concentration of both $\mathrm{Pb}$ and $\mathrm{Zn}$. The measured concentrations of toxic metals were within the range measured in other studies [21-40], except for the $\mathrm{Cr}$ content in Rya-Fa, that was less than previously observed and the $\mathrm{Zn}$ content in Arc-Fa2 that was higher than previously observed.

Cadmium leaching was below the detection limit of $0.01 \mathrm{mg} / \mathrm{kg}$ for the samples Arc-Fa1, Nuuk-Fa2 and Rya-Fa, while Nuuk-Fa1 leached $0.7 \mathrm{mg} / \mathrm{kg}$ and Arc-Fa2 leached $432.8 \mathrm{mg} / \mathrm{kg}$. The leached amounts of $\mathrm{Cr}$ and $\mathrm{Cu}$ follow the total content measured, where the samples with the highest total concentration also had the highest leached concentration. This is not the case for $\mathrm{Pb}$. The sample Arc-Fa2 had the highest concentration of $\mathrm{Pb}$ and leached the least, while Rya-Fa leached approximately a third of its concentration of $\mathrm{Pb}$. The five fly ash samples all contained high amounts of $\mathrm{Zn}$ and leached between 4.0 and $19.8 \mathrm{mg} \mathrm{Zn/kg}$, while Arc-Fa2 leached an exponentially high amount of $\mathrm{Zn}$ compared to the other samples at $22.9 \mathrm{~g} / \mathrm{kg}$.

No limits exist for toxic metal leaching from waste materials to be used as SCMs, the leaching limits for waste materials used for geotechnical purposes (Category 3, Restproduktbekendtgørelsen [47]) was therefore used instead. The specified limits were recalculated from $\mu \mathrm{g} / \mathrm{l}$ to $\mathrm{mg} / \mathrm{kg}$. The studied MSWI fly ash samples exceeded the specified limits for $\mathrm{Pb}$ and $\mathrm{Zn}$ leaching, while Arc-Fa2 and Nuuk-Fa1 exceeded the limits for $\mathrm{Cd}$. The sample Rya-Fa exceeded the limit for Cu leaching and was the only sample with leaching lower than the $\mathrm{Cr}$ limit.

\subsection{Physical properties}

The particle size distributions of the five MSWI fly ash samples are shown in Fig. 3, while the corresponding d-values are shown in Table 5. Arc-Fa1 consisted of finer particles than both Rya-Fa and Nuuk-Fa1, with a $\mathrm{d}_{10}$ similar to CEM I cement. Approximately $30 \%$ of Arc-Fa 1 consisted of particles smaller than $10 \mu \mathrm{m}$, compared to around $10-15 \%$ for Nuuk-Fa1 and Rya-Fa. However, Arc-Fa1 also contained coarser particles than Rya-Fa and Nuuk-Fa1. The sample Arc-Fa2 deviated from Arc-Fa1 with a higher $d_{10}$ value, smaller $d_{50}$ and $d_{90}$ values and approximately $13 \%$ of its particles less than $10 \mu \mathrm{m}$ in diameter. Both Arc-Fa samples contained particles over the fine particle limit specified by Moosberg-Bustnes et al. [11]. The sample Nuuk-Fa2 deviated from Nuuk-Fa1 as well, resembling CEM-I cement instead. Approximately $40 \%$ of Nuuk-Fa2 consisted of particles with a diameter of less than $10 \mu \mathrm{m}$.

According to Moosberg-Bustnes et al. [11], the addition of fine particles, with a maximum size of $125 \mu \mathrm{m}$, to a cement-based material has a physical effect, filling intergranular voids, improving the packing density and

Table 4 Total toxic metal concentration in the five MSWI fly ash samples as well as leached concentrations

\begin{tabular}{|c|c|c|c|c|c|c|c|}
\hline $\begin{array}{l}\text { Total-content } \\
\text { (mg/kg) }\end{array}$ & Arc-Fa1 & Arc-Fa2 & Nuuk-Fa1 & Nuuk-Fa2 & Rya-Fa & CEM I & MSWI [20-39] \\
\hline $\mathrm{Cd}$ & $280 \pm 5$ & $410 \pm 9$ & $205 \pm 6$ & $284 \pm 7$ & $62.7 \pm 4.3$ & $0.4 \pm 0.3$ & $22-578$ \\
\hline $\mathrm{Cr}$ & $126 \pm 2$ & $109 \pm 2$ & $206 \pm 7$ & $336 \pm 9$ & $23.1 \pm 1.5$ & $33.7 \pm 0.7$ & $47-2026$ \\
\hline $\mathrm{Cu}$ & $1070 \pm 20$ & $1360 \pm 24$ & $755 \pm 16$ & $940 \pm 34$ & $6940 \pm 870$ & $139.6 \pm 3$ & $168-7800$ \\
\hline $\mathrm{Pb}$ & $6250 \pm 230$ & $15,290 \pm 780$ & $2750 \pm 61$ & $3140 \pm 96$ & $3630 \pm 450$ & $16.7 \pm 0.5$ & $319-36,420$ \\
\hline $\mathrm{Zn}$ & $34,690 \pm 1360$ & $66,560 \pm 2110$ & $29,630 \pm 830$ & $23,070 \pm 630$ & $6860 \pm 830$ & $184 \pm 15$ & $2-65,170$ \\
\hline $\begin{array}{l}\text { Leached (mg/ } \\
\mathrm{kg} \text { ) }\end{array}$ & & & & & \multicolumn{3}{|c|}{ Category 3 [47] } \\
\hline $\mathrm{Cd}$ & $<0.01$ & $433 \pm 10$ & $0.7 \pm 0.2$ & $<0.01$ & $<0.01$ & 0.08 & - \\
\hline $\mathrm{Cr}$ & $1.5 \pm 1.6$ & $0.9 \pm 0.0$ & $19.5 \pm 2.7$ & $39.2 \pm 4.4$ & $0.1 \pm 0.0$ & 1 & - \\
\hline $\mathrm{Cu}$ & $0.2 \pm 0.0$ & $2.6 \pm 0.1$ & $0.3 \pm 0.2$ & $0.4 \pm 0.2$ & $51.7 \pm 2.1$ & 4 & - \\
\hline $\mathrm{Pb}$ & $49.5 \pm 3.4$ & $5.0 \pm 0.1$ & $16.4 \pm 1.8$ & $530 \pm 11$ & $1400 \pm 110$ & 0.2 & - \\
\hline $\mathrm{Zn}$ & $10.4 \pm 0.6$ & $22,950 \pm 610$ & $4.0 \pm 0.7$ & $5.8 \pm 0.2$ & $19.8 \pm 0.9$ & 3 & - \\
\hline
\end{tabular}




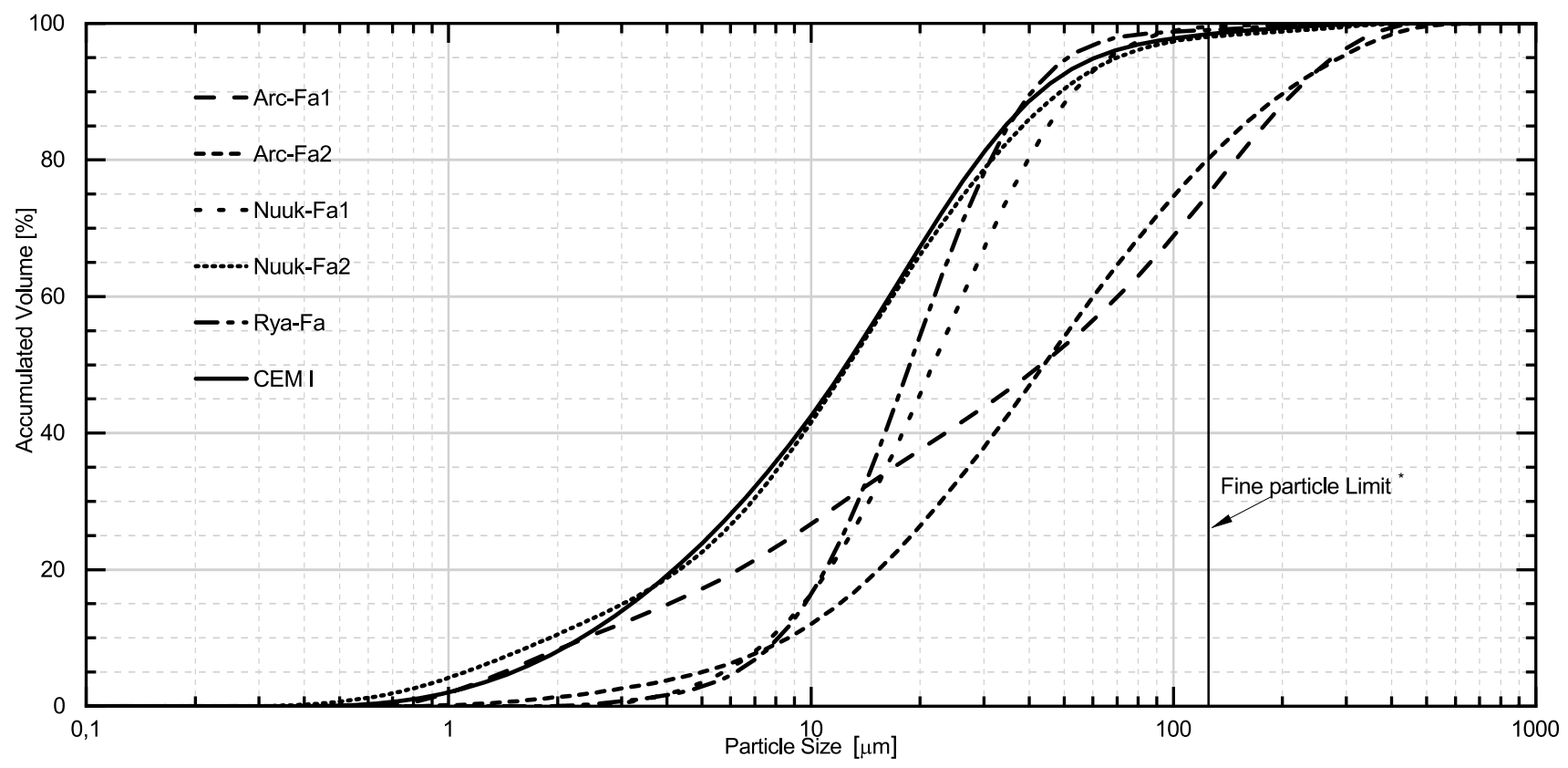

Fig. 3 The particle size distribution of the five MSWI fly ash samples and CEM I cement. *Fine particle limit as suggested by MoosbergBustnes et al. [11]

Table $5 \mathrm{~d}$-Values $(\mu \mathrm{m})$ of the five MSWI fly ash samples

\begin{tabular}{lccrrr}
\hline & Arc-Fa1 & Arc-Fa2 & Nuuk-Fa1 & Nuuk-Fa2 & \multicolumn{1}{c}{ Rya-Fa } \\
\hline $\mathrm{d}_{10}$ & $2.8 \pm 0.2$ & $8.7 \pm 0.2$ & $7.8 \pm 0.3$ & $1.9 \pm 0.0$ & $8.3 \pm 0.7$ \\
$\mathrm{~d}_{50}$ & $49.6 \pm 1.9$ & $44.0 \pm 0.9$ & $21.7 \pm 0.7$ & $12.7 \pm 0.2$ & $18.7 \pm 0.2$ \\
$\mathrm{~d}_{90}$ & $248 \pm 5$ & $204 \pm 8$ & $52.9 \pm 1.2$ & $48.8 \pm 1.2$ & $40.7 \pm 2.7$ \\
\hline
\end{tabular}

a surface chemical effect enhancing the hydration by offering more nucleation sites. According to Scrivener et al. [12], the hydration enhancement is only possible for materials that have a finer particle size distributions than cement. Filler materials may also increase the degree of hydration through dilution by increasing the space for clinker hydrate formation [12]. The five MSWI fly ash samples had particle size distributions that were larger than or similar to CEM I cement and were within the fine particle limit, except the Arc samples. Although the samples are within the fine particle limit, they are not expected to improve the packing density or enhance hydration as nucleation sites, due to their larger particle size distribution than CEM I cement, except the sample Nuuk-Fa2. The sample Nuuk-Fa2 had a particle size distribution like CEM I and had a $d_{10}$ value less than CEM and could potentially improve the packing density. The five MSWI fly ash samples would, therefore, be limited to increasing the degree of hydration through dilution.

\subsection{Variability of MSWI fly ash}

The results of the principal component analysis (PCA) are shown in Fig. 4 for the 1st and 2nd principal components and Fig. 5 for the 1st and 3rd components. Included are plots of the loadings and the scores.

In a loading plot, variables close to the origin has little contribution to a sample's score [48]; this was the case for $\mathrm{Cu}$ (see Fig. 4a) which has limited weight on the 1st and 2nd principal components. Strongly correlated variables cluster together in a loading plot [48], this is observable in Fig. 4a for (1) $\mathrm{SiO}_{2}, \mathrm{Al}_{2} \mathrm{O}_{3}, \mathrm{Fe}_{2} \mathrm{O}_{3}$ and $\mathrm{MgO}$ and (2) $\mathrm{Cd}, \mathrm{Zn}$, $\mathrm{Pb}$ and $\mathrm{SO}_{3}$. Samples with a high content of $\mathrm{SiO}_{2}$ can be expected to have a high content of $\mathrm{Al}_{2} \mathrm{O}_{3}, \mathrm{Fe}_{2} \mathrm{O}_{3}$ and $\mathrm{MgO}$ as well, while samples with a high content of $\mathrm{Cd}$, might contain a high amount of $\mathrm{Zn}, \mathrm{Pb}$ and $\mathrm{SO}_{3}$. Negatively correlated variables appear diagonally of each other in a loading plot [48]. This can be observed for $\mathrm{Cl}$ in Fig. 4a that is negatively correlated with $\mathrm{SiO}_{2}, \mathrm{Al}_{2} \mathrm{O}_{3}, \mathrm{Fe}_{2} \mathrm{O}_{3}$ and $\mathrm{MgO}$, indicating that $\mathrm{MSWI}$ fly ash with a high content of $\mathrm{Cl}$ contains less $\mathrm{SiO}_{2}, \mathrm{Al}_{2} \mathrm{O}_{3}, \mathrm{Fe}_{2} \mathrm{O}_{3}$ and $\mathrm{MgO}$.

In a score plot, samples with variables close to the average appear at the origin, while samples further out are outliers or naturally extreme observations in the data set [48]. This can be observed in Fig. $4 \mathrm{~b}$ for the 1 st and 2nd principal components. Several of the MSWI fly ash samples in the dataset were located close to the origin indicating that they have a common composition, while several samples are further away, indicating that those particular 


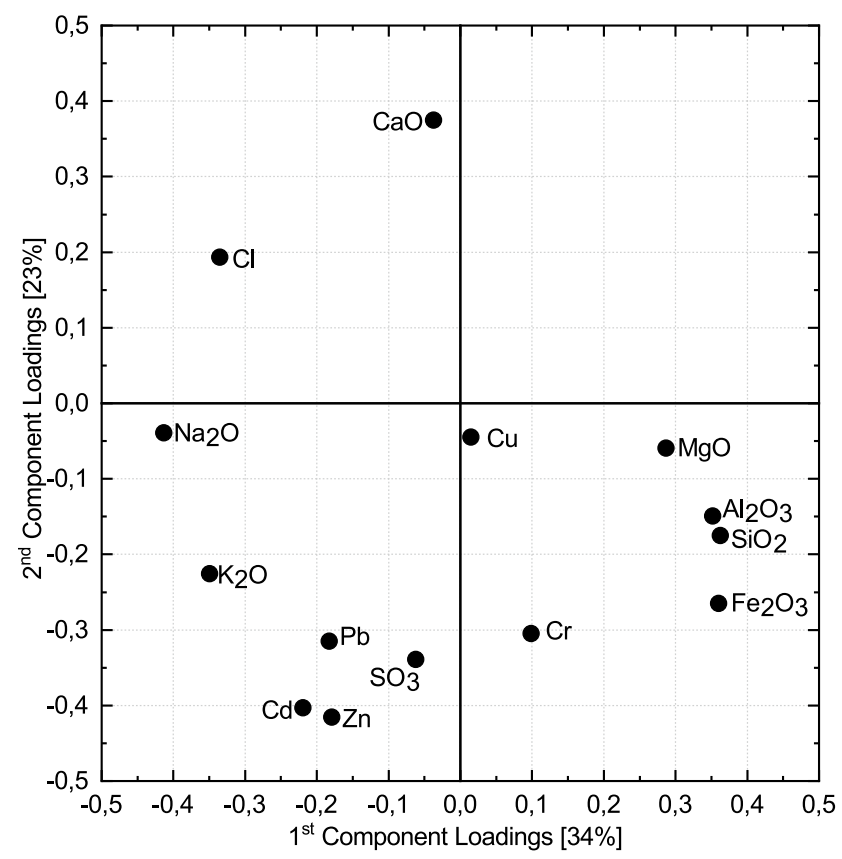

Fig. 4 PCA results for the 1 st and 2 nd principal components, loading plot (left, a) of the variables and score plot (right, b) of the observations. Black symbols are from grate furnaces, while grey

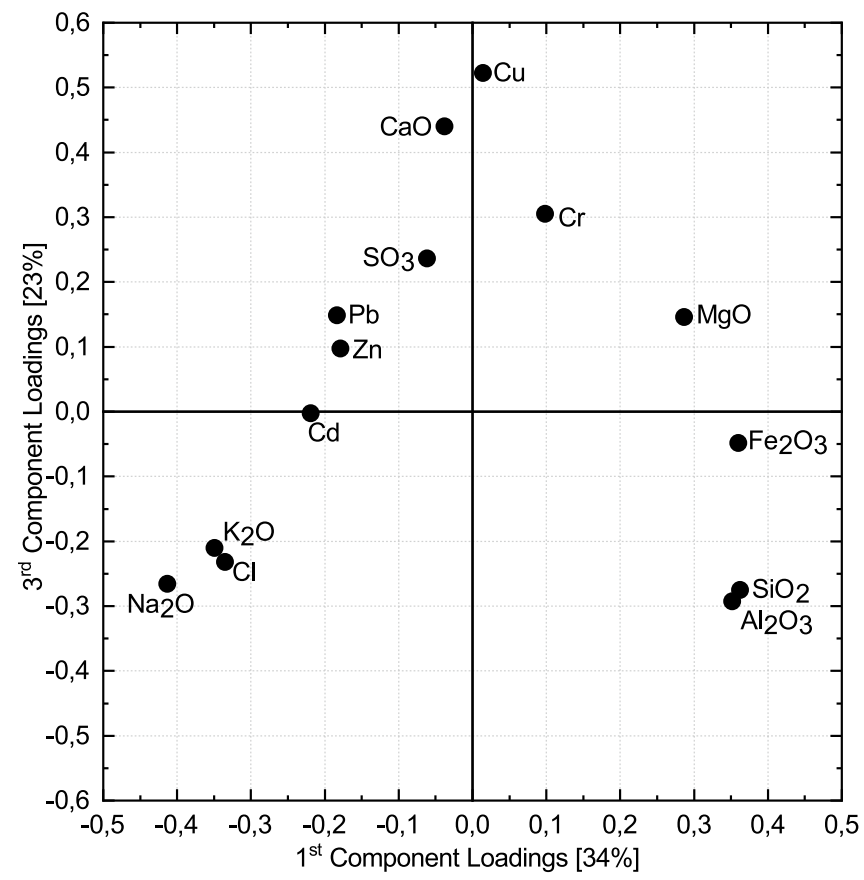

Fig. 5 PCA results for the 1st and 3rd principal components, loading plot (left, a) of the variables and score plot (right, b) of the observations. Black symbols are from grate furnaces, while grey

MSWI fly ash samples have a unique composition. This can be observed for the included coal fly ash sample. The reason for a sample's score can, in general, be inferred by

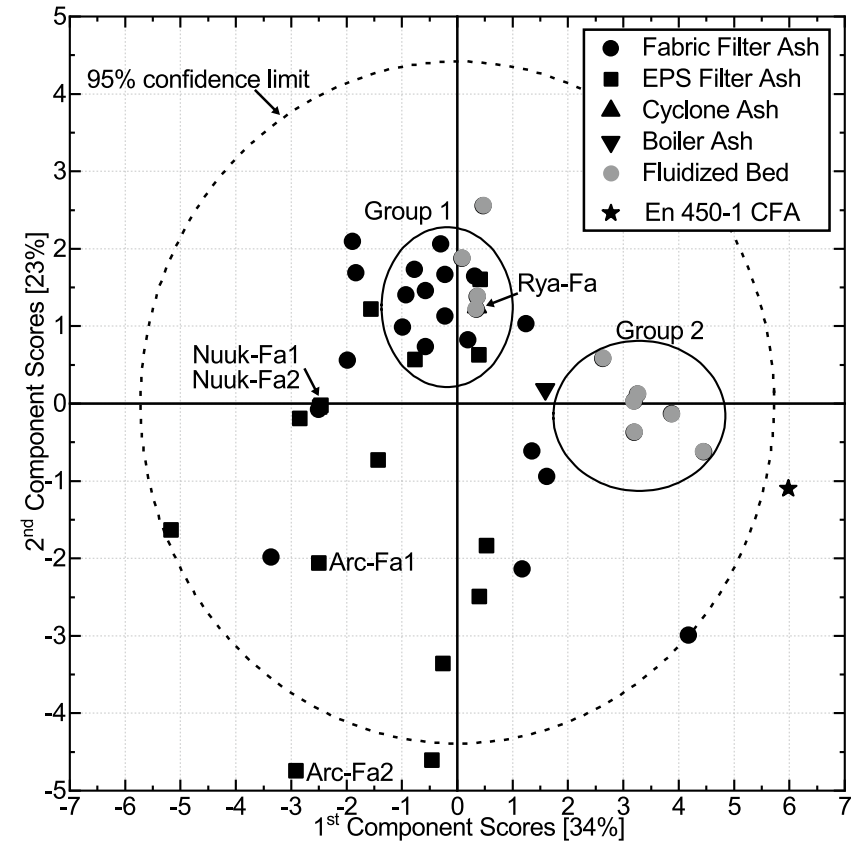

symbols are fabric filter ash from fluidised bed furnaces. Included in the score plot is an EN 450-1 coal fly ash (CFA). Two clusters are marked as group 1 and 2

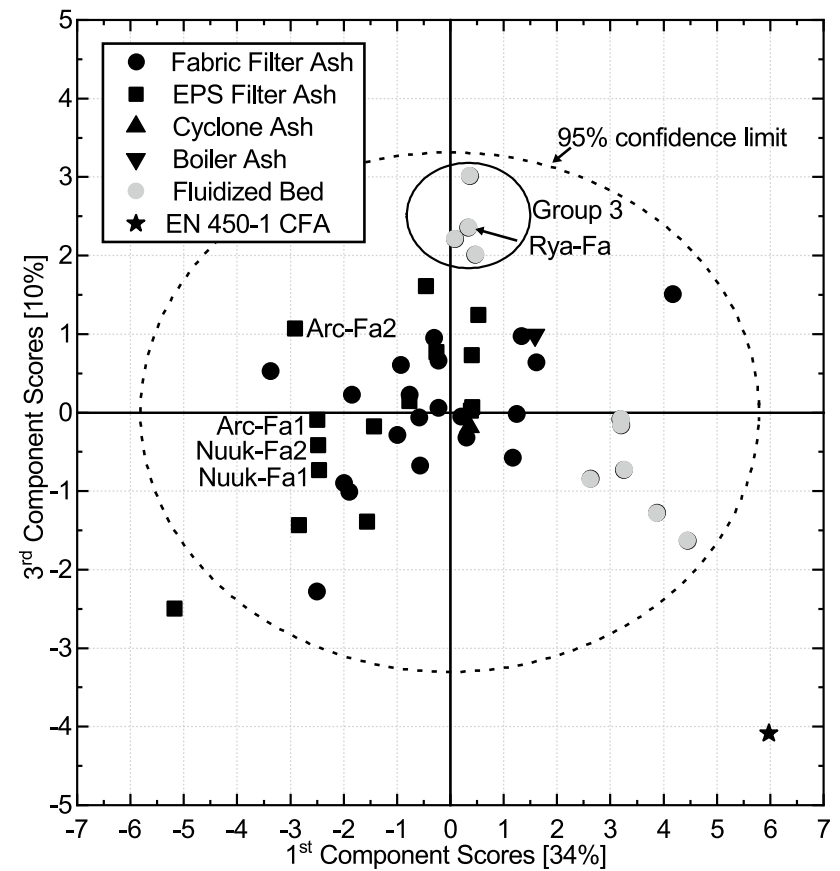

symbols are fabric filter ash from fluidised bed furnaces. Included in the score plot is an EN 450-1 coal fly ash (CFA). A cluster of samples are marked as Group 3

cross-referencing with the loading plot [48]. In Fig. 4b, samples with a high positive 1st principal component are therefore expected to have an above-average content of 
$\mathrm{SiO}_{2}, \mathrm{Al}_{2} \mathrm{O}_{3}, \mathrm{Fe}_{2} \mathrm{O}_{3}$ and $\mathrm{MgO}$. In contrast, samples with a large negative 1 st principal component are expected to have an above-average content of $\mathrm{Na}_{2} \mathrm{O}, \mathrm{K}_{2} \mathrm{O}$ and $\mathrm{Cl}$. Similar observations were made for the 2 nd principal component where $\mathrm{CaO}$ is negatively correlated with $\mathrm{Pb}, \mathrm{Cd}, \mathrm{Zn}$ and $\mathrm{SO}_{3}$.

The score plot in Fig. $4 \mathrm{~b}$ for the 1 st and 2nd principal components indicated that approximately half of the MSWI fly ash samples of the dataset had a negative 1st principal component, while the other half had a positive 1 st principal component. This difference appears to partly depend on the furnace type used for incineration. The fluidised bed samples had positive 1st principal components indicating a higher than average content of $\mathrm{SiO}_{2}, \mathrm{Al}_{2} \mathrm{O}_{3}$, $\mathrm{Fe}_{2} \mathrm{O}_{3}$ and $\mathrm{MgO}$, while the majority of the grate furnace samples had a negative 1st principal component, indicating a higher than average content of $\mathrm{Na}_{2} \mathrm{O}, \mathrm{K}_{2} \mathrm{O}$ and $\mathrm{Cl}$. A difference between fabric filter ash and electrostatic precipitator (ESP) ash was observed for the 2nd principal component. Ash from a fabric filter appeared to have a higher content of $\mathrm{CaO}$ than ESP ash, while ESP ash had a higher content of $\mathrm{Pb}, \mathrm{Cd}, \mathrm{Zn}$ and $\mathrm{SO}_{3}$ than fabric filter ash, which could be due to the addition of air pollution control products in the form of lime.

Marked in the score plot for the 1st and 2nd component, see Fig. 5b, are two clusters marked as Group 1 and 2. Group 1 consists of a third of the dataset and includes samples from both grate and fluidized bed incinerators as well as samples from fabric and EPS filters. The samples in Group 1 originated from several different countries and also included one cyclone ash from a grate fired furnace. Group 2 consists of a cluster of MSWI fly ash samples from Chinese fluidised bed incinerators with a higher than average content of $\mathrm{SiO}_{2}, \mathrm{Al}_{2} \mathrm{O}_{3}, \mathrm{Fe}_{2} \mathrm{O}_{3}$ and $\mathrm{MgO}$ otherwise not observed in MSWI fly ash. This could be a result of the incinerator design or fuel used during incineration.

In the loading plot between the 1st and 3rd principal components, see Fig. $5 \mathrm{a}$, $\mathrm{Cu}$ had a larger contribution to the samples' 3 rd principal components score. The fluidised bed samples which were part of Group 1 in Fig. 4b were clustered separately along the 3rd principal component indicating a higher than average content of $\mathrm{Cu}$ in the samples, see Group 3 in Fig. 5b. The samples in Group 3 were from Swedish incinerators that the incinerator design or fuel used results in a higher $\mathrm{Cu}$ content.

The included coal fly ash sample was an outlier in both score plots, Figs. $4 \mathrm{~b}$ and $5 \mathrm{~b}$, with a high content of $\mathrm{SiO}_{2}$, $\mathrm{Al}_{2} \mathrm{O}_{3}$ and $\mathrm{Fe}_{2} \mathrm{O}_{3}$. The MSWI fly ash samples from fluidised bed incinerators in Group 2, had the closest scores to the coal fly ash sample, indicating the closest similar composition.

The sample Arc-Fa2 from the present study was an outlier in the dataset, with a 1st and 2nd principal component score of approximately -3 and -5 , respectively. The sample Arc-Fa2 had an above-average content of $\mathrm{SO}_{3}, \mathrm{~Pb}$, $\mathrm{Zn}$ and $\mathrm{Cd}$ not observed in other MSWI fly ash samples, that could be considered uncommon for MSWI fly ash. The sample Arc-Fa1 had a score closer to the rest of the samples. Although the sample Arc-Fa1 was not an outlier, it was not part of any cluster, suggesting a composition that is less common for MSWI fly ash. The samples NuukFa1 and Nuuk-Fa2 had similar scores, indicating that the two samples are similar in terms of oxide and toxic metal content. The two samples from Nuuk were outside of Group 1 with a higher than average content of $\mathrm{Cl}, \mathrm{Na}_{2} \mathrm{O}$ and $\mathrm{K}_{2} \mathrm{O}$ compared to $\mathrm{SiO}_{2}, \mathrm{Al}_{2} \mathrm{O}_{3}$ and $\mathrm{Fe}_{2} \mathrm{O}_{3}$ and could be considered less common of MSWI fly ash. The sample RyaFa was a part of Group 1, indicating a common chemical composition.

\section{Discussion}

Samples from fluidized bed incinerators had positive 1st components, while the majority of the grate furnace samples had negative 1st components. Samples from fabric filters had predominantly positive 2 nd components, while samples from electrostatic precipitators had predominantly negative 2 nd components. However, the scattering observed for dataset samples originating from grate furnaces and either EPS or fabric filters, suggested that similar chemical compositions can be found regardless of the incineration plant design. Parts of the dataset were clustered, while the rest of the dataset were scattered, indicating that a typical oxide composition and toxic metal content can to some extent be found for MSWI fly ash, regardless of the origins of the sample. The coal fly ash was an outlier compared to the MSWI fly ash samples of the dataset, indicating that the MSWI fly ash samples differed considerably from EN 450-1 2012 coal fly ash. The fluidised bed samples in Group 2 had the closest scores, suggesting that these samples were closest in chemical composition to EN 450-1 2012 coal fly ash. The samples in Group 2 could be the best suited MSWI fly ash samples for use in cementbased materials. None of the samples in the present study were found in this cluster.

The PCA indicated that the samples Arc-Fa1 and Arc$\mathrm{Fa} 2$ differed significantly both from each other and previously studied MSWI fly ash samples, containing $\mathrm{SO}_{3}, \mathrm{~Pb}$, $\mathrm{Zn}$ and $\mathrm{Cd}$ in high amounts. However, the total content of $\mathrm{SO}_{3}, \mathrm{~Pb}, \mathrm{Zn}$ and $\mathrm{Cd}$ in Arc-Fa2 was noticeably higher than in Arc-Fa1, making it a different material as indicated by the differences in DTG curves and XRD patterns. The sample Arc-Fa2 was an outlier in the dataset, while Arc-Fa1 was spread out from any clustering, suggesting that the high contents of $\mathrm{SO}_{3}, \mathrm{~Pb}, \mathrm{Zn}$ and $\mathrm{Cd}$ were uncommon for 
MSWI fly ash and that the samples were unrepresentative of MSWI fly ash. The samples from Nuuk had similar PCA scores, indicating that the two samples were very similar in chemical composition. Their scores were closer to the majority of the dataset as well, indicating a less unique chemical composition compared to the Arc samples. The sample Rya-Fa was part of the cluster Group 1 and the closest to the dataset average out of the five MSWI fly ash samples in the present study and could be considered a representative sample for MSWI fly ash. Rya-Fa could, therefore, give a general impression of the effect MSWI fly ash has in cement-based materials. However, studying all five MSWI fly ash samples can give a deep impression of the impact MSWI fly ash has in cement-based materials.

Additionally, the PCA indicated that multivariate statistical methods could be used as a tool to evaluate how representative new MSWI fly ash samples are to previously studied samples. This is especially the case for the sample Arc-Fa2 that otherwise appeared to be within the limits of previously observed MSWI fly ash samples.

The five MSWI fly ash samples evaluated in the present study had PCA scores that varied from EN 450-1 coal fly ash and did not fulfil the chemical requirements specified in EN 450-1 2012 [10]. Using the five MSWI fly ash samples in cement-based materials could potentially result in several drawbacks. Pozzolanic reactions in cement-based materials occur between $\mathrm{Ca}(\mathrm{OH})_{2}$ and amorphous $\mathrm{SiO}_{2}$ forming $\mathrm{C}-\mathrm{S}-\mathrm{H}$ or with amorphous aluminosilicate forming $\mathrm{C}-\mathrm{A}-\mathrm{H}$ phases or $\mathrm{C}-\mathrm{A}-\mathrm{S}-\mathrm{H}$ phases, Justness [2]. Hamernik and Frantz [41] studied MSWI fly ashes with a combined content of $\mathrm{SiO}_{2}, \mathrm{Fe}_{2} \mathrm{O}_{3}$ and $\mathrm{Al}_{2} \mathrm{O}_{3}$ above $50 \mathrm{wt} \%$. They analysed the pozzolanic activity index of paste samples with $35 \%$ cement replaced by MSWI fly ash and concluded that the MSWI fly ashes had pozzolanic activity indexes comparable to coal fly ash and showed no cementitious properties when mixed with water. The MSWI fly ashes of the present study had a low content of $\mathrm{SiO}_{2}, \mathrm{Fe}_{2} \mathrm{O}_{3}$ and $\mathrm{Al}_{2} \mathrm{O}_{3}$ and would have limited pozzolanic activity if used in cement-based materials.

The differences between the particle size distributions of the five MSWI fly ash samples and CEM I cement indicate that the potential of the samples as filler materials are limited to increasing the degree of hydration through dilution. Although, with a small enough particle size distribution as observed for Nuuk-Fa2, the packing density could potentially be improved. However, the oxide composition and soluble content of $\mathrm{Cl}^{-} \mathrm{SO}_{4}{ }^{2-}, \mathrm{K}^{+}, \mathrm{Na}^{+}$and $\mathrm{Ca}^{+}$in the five MSWI fly samples indicates that they would not be inert filler, limiting their potential as filler materials.

Research has shown that an increasing sulphate level can reduce the heat of hydration, increase setting time and reduce the strength of a cement-based material [49]. The samples Arc-Fa1 and Arc-Fa2 could be expected to have a significant negative impact on these factors. Alkali-aggregate reactions occur in cement-based materials between alkalis (sodium and potassium) and specific aggregate types and may result in cracking [50]. The Arc and Nuuk samples all had a high $\mathrm{Na}_{2} \mathrm{O}_{\text {eq }}$ content as well as soluble $\mathrm{Na}^{+}$and $\mathrm{K}^{+}$and could be expected to cause alkali-aggregate reactions if used in conjunction with reactive aggregates. The sample Rya-Fa exceeded the limit by $2.8 \mathrm{wt} \%$ and could cause alkali-aggregate reactions as well to a lesser extent. Chloride ions in reinforced cement-based materials can destroy the passive iron oxide film, leading to corrosion of the steel [50]. The measured calcium could be present as $\mathrm{CaCO}_{3}$ in the fly ash samples. $\mathrm{CaCO}_{3}$ can interact with the $\mathrm{AFm}$ and $\mathrm{AFt}$ phases in hydrating cement, resulting in the formation of carboaluminates, stabilizing the ettringite and improving the mechanical properties [51]. However, the interaction with $\mathrm{CaCO}_{3}$ requires additional aluminates brought into the system [51]. The aluminate content range of MSWI fly ash is low compared to coal fly ash [42], limiting the beneficial interaction with the AFm and AFt phases.

No Danish standards exist regarding heavy metal content in cement-based materials when using MSWI ash. The limits for sewage sludge ash as specified in DS/EN 206 DK NA:2018 [52] are used for comparison instead. According to DS/EN 206 DK NA:2018 [52], using sewage sludge ash in concrete should not increase the heavy metal content by more than $25 \%$. An increase of $50 \%$ can be accepted if the original heavy metal content in the concrete is low. The $\mathrm{Cd}$ content in the Arc and Nuuk samples was the most critical metal, exceeding the $50 \%$ criteria at $0.05-0.1 \%$ cement replacement. The sample Rya-Fa increases the $\mathrm{Pb}$ above $50 \%$ at $0.23 \%$ cement replacement. Toxic metals can be chemically bound in cement-based materials due to the high pH in Portland cement [6]. However, this does not account for decommissioning or reductions in $\mathrm{pH}$ due to, e.g. carbonation or chloride ingress [53].

Pre-treatment would be required before the studied MSWI fly ash samples can be used in cement-based materials. The pre-treatment method should reduce the toxic metal concentrations and leaching as well as improve the oxide composition. Additionally, the pretreatment could reduce the particle size distribution as well, improving the ashes potential as filler materials. Several potential methods of improving MSWI fly ash has been investigated, such as washing the MSWI fly ash to reduce chloride and toxic metal content [54] or thermal methods such as vitrification [55]. Another potential method is electrodialytic remediation that reduces the chloride and toxic metal content, increasing the fraction of $\mathrm{SiO}_{2}, \mathrm{Fe}_{2} \mathrm{O}_{3}$ and $\mathrm{Al}_{2} \mathrm{O}_{3}$ [56]. Milling MSWI fly ash could be an effective method to both improve the particle size distribution and treat MSWI fly ash [57]. 


\section{Conclusions}

The multivariate modelling indicated that the samples ArcFa1 and Arc-Fa2 were not representative of MSWI fly ash due to their high content of $\mathrm{SO}_{3}, \mathrm{~Pb}, \mathrm{Zn}$ and $\mathrm{Cd}$ and that the two samples were chemically different materials. The samples Nuuk-Fa1 and Nuuk-Fa2 were similar and more representative of MSWI fly ash. The sample Rya-Fa was the most common of the five MSWI fly ash samples investigated in the present study and could provide the most representative result if used in cement-based materials.

It was determined that the chemical composition was in part, dependent on the furnace and filter type used during incineration. However, similar MSWI fly ash samples could be found in literature, regardless of the furnace or filter type used during incineration.

MSWI fly ash differed significantly from a coal fly ash that fulfils the requirements of EN 450-1 2012. The five MSWI fly ash samples investigated did not fulfil eight of the ten chemical requirements specified in EN 450-1 2012. The investigated samples had particle sizes comparable to and slightly larger than cement and had limited potential as filler material. However, negative effects from the $\mathrm{SO}_{3}$, $\mathrm{Cl}$ and alkali metal and the total toxic and leached metal concentrations limit their potential use in cement-based materials without pre-treatment.

Acknowledgements Amager Resource Center is acknowledged for their cooperation in obtaining ash from their facility. Furthermore, Kommuneqarfik Semersooq and Borås Energy och Miljö, are acknowledged for sampling and sending the MSWI fly ash samples from the Nuuk incinerator in Greenland and Ryaverket in Sweden. Finally, the lab technicians Ebba Schnell, Malene Møller, Anna Schroeder and Natasja Dueholm are recognised for their assistance in measuring the many properties of the MSWI fly ashes. The corresponding author would like to thank Nina Marie Sigvardsen and Kristine Bondo Pedersen for their support with the principal component analysis.

\section{Compliance with ethical standards}

Conflict of interest On behalf of all authors, the corresponding author states that there is no conflict of interest.

\section{References}

1. Olivier JGJ, Janssens-Maenhout G, Muntean M, Peters JAHW (2016) Trends in global $\mathrm{CO}_{2}$ emissions, 86, PBL Netherlands environmental service

2. Justnes $H$ (2015) Influence of SCMs on hydration and durability of blended cements-chemical and physical principles. J Chin Ceram Soc 2554(13):1359-1371

3. Scrivener KL, John VM, Gartner EM (2016) Eco-efficient cements: potential, economically viable solutions for a low- $\mathrm{CO}_{2}$, cement based materials industry. United Nations Environment Program
4. Zhang H, Zhao Y (2009) Toxicity analysis of municipal solid waste incineration (MSWI) fly ash. In: 2009 3rd international conference on bioinformatics and biomedical engineering, pp 1-4

5. Ferreira C, Ribeiro A, Ottosen L (2003) Possible applications for municipal solid waste fly ash. J Hazard Mater 96:201-216

6. Kozakova L, Bakalar T, Zelenak M, Prascakova M (2013) Solidification of MSWI fly-ash with regard to hazardous metals leaching. Acta Montan Slov 18:129-139

7. Aubert JE, Husson B, Vaquier A (2004) Use of municipal solid waste incineration fly ash in concrete. Cem Concr Res 34:957-963

8. Aubert JE, Husson B, Sarramone N (2006) Utilization of municipal solid waste incineration (MSWI) fly ash in blended cement. Part 1: processing and characterization of MSWI fly ash. J Hazard Mater 136:624-631

9. Lenormand $T$, Rozière $E$, Loukili $A$, Staquet $S$ (2015) Incorporation of treated municipal solid waste incineration electrostatic precipitator fly ash as partial replacement of Portland cement: effect on early age behaviour and mechanical properties. Constr Build Mater 96:256-269

10. DS/EN 450-1: Flyveaske til beton-Del 1 : Definition, specifikationer og overensstemmelses-kriterier; Dansk Standard (2012)

11. Moosberg-Bustnes $H$, Lagerblad B, Forssberg E (2004) The function of fillers in concrete. Mater Struct Constr 37:74-81

12. Scrivener KL, Lothenbach B, De Belie N, Gruyaert E, Snellings R, Vollpracht A (2015) TC 238-SCM: hydration and microstructure of concrete with SCMs state of the art on methods to determine degree of reaction of SCMs. Mater Struct 48:835-862

13. Pedersen KB, Kirkelund GM, Ottosen LM, Jensen PE, Lejon $T$ (2015) Multivariate methods for evaluating the efficiency of electrodialytic removal of heavy metals from polluted harbour sediments. J Hazard Mater 283:712-720

14. Sigvardsen NM, Kirkelund GM, Jensen PE, Geiker MR, Ottosen LM (2019) Impact of production parameters on physiochemical characteristics of wood ash for possible utilisation in cementbased materials. Resour Conserv Recycl 145:230-240

15. Voshell S, Mäkelä M, Dahl O (2018) A review of biomass ash properties towards treatment and recycling. Renew Sustain Energy Rev 96:479-486

16. Javan H (1999) Application of Mie theory to large particle. In: Proceedings of the conference proceedings-IEEE SOUTHEASTCON, vol 1999-March, pp 237-241

17. Chen W, Kirkelund GM, Jensen PE, Ottosen LM (2017) Comparison of different MSWI fly ash treatment processes on the thermal behavior of $\mathrm{As}, \mathrm{Cr}, \mathrm{Pb}$ and $\mathrm{Zn}$ in the ash. Waste Manag 68:240-251

18. DS/EN 12457-1 (2002) Characterisation of waste-LeachingCompliance test for leaching of granular waste materials and Sludges-Part 1: One stage batch test at a liquid to solid ratio of $2 \mathrm{l} / \mathrm{kg}$ for materials with high solid content and with particle size bel; Dansk Standard

19. DS 259 (2003) Vandundersøgelse-Bestemmelse af metaller $i$ vand, jord, slam og sedimenter-Almene principper og retningslinjer for bestemmelse ved atomabsorptionsspektrofotometri i flamme Determination of metals in water, sludge and atomic absorption; Dansk Standard

20. Tefas A, Pitas I (2016) Principal component analysis. Intell Syst 2:37-52

21. Ni P, Li H, Zhao Y, Zhang J, Zheng C (2017) Relation between leaching characteristics of heavy metals and physical properties of fly ashes from typical municipal solid waste incinerators. Environ Technol 38:2105-2118

22. Qiu Q, Jiang X, Chen Z, Lu S, Ni M (2017) Microwave-assisted hydrothermal treatment with soluble phosphate added for heavy metals solidification in MSWI fly ash. Energy Fuels 31:5222-5232 
23. LiW, Sun Y, Huang Y, Shimaoka T, Wang H, Wang YN, Ma L, Zhang D (2019) Evaluation of chemical speciation and environmental risk levels of heavy metals during varied acid corrosion conditions for raw and solidified/stabilized MSWI fly ash. Waste Manag 87:407-416

24. Mu Y, Saffarzadeh A, Shimaoka T (2018) Influence of ignition of waste fishbone on enhancing heavy metal stabilization in municipal solid waste incineration (MSWI) fly ash. J Clean Prod 189:396-405

25. Kitamura H, Dahlan AV, Tian Y, Shimaoka T, Yamamoto T, Takahashi F (2019) Intra- and inter-particle heterogeneity of municipal solid waste incineration fly ash particles. J Mater Cycles Waste Manag 21:925-941

26. Ma W, Chen D, Pan M, Gu T, Zhong L, Chen G, Yan B, Cheng Z (2019) Performance of chemical chelating agent stabilization and cement solidification on heavy metals in MSWI fly ash: a comparative study. J Environ Manag 247:169-177

27. Zhu F, Xiong Y, Wang Y, Wei X, Zhu X, Yan F (2018) Heavy metal behavior in "Washing-Calcination-Changing with Bottom Ash" system for recycling of four types of fly ashes. Waste Manag 75:215-225

28. De Boom A, Aubert J, Degrez M (2014) Carbonation of municipal solid waste incineration electrostatic precipitator fly ashes in solution. Waste Manag Res 32:406-413

29. Kirkelund GM, Dias-Ferreira C, Jensen PE (2016) Characterization of particulate residues from greenlandic mswi for use as secondary resources. In: Proceedings of the international conference materials, systems and structures in civil engineering 2016: workshop on cold region engineering, Nyt Teknisk Forlag, pp 27-36

30. Weibel G, Eggenberger U, Schlumberger S, Mäder UK (2017) Chemical associations and mobilization of heavy metals in fly ash from municipal solid waste incineration. Waste Manag 62:147-159

31. Bayuseno AP, Schmahl WW, Müllejans T (2009) Hydrothermal processing of MSWI fly ash-towards new stable minerals and fixation of heavy metals. J Hazard Mater 167:250-259

32. Chimenos JM, Ferna AI (2005) Optimizing the APC residue washing process to minimize the release of chloride and heavy metals. Waste Manag 25:686-693

33. Fedje KK, Ekberg C, Skarnemark G, Pires E, Steenari B (2012) Initial studies of the recovery of Cu from MSWI fly ash leachates using solvent extraction. Waste Manag Res 30:1072-1080

34. Liu F, Liu J, Yu Q, Jin Y, Nie Y (2007) Leaching characteristics of heavy metals in municipal solid waste incinerator fly ash. J Environ Sci Heal 40(10):1975-1985

35. Wang L, Li R-D, Wei L, Li Y (2012) Accelerated carbonation of municipal solid waste incineration fly ash using $\mathrm{CO}_{2}$ as an acidic agent for clinker production. Environ Eng Sci 29:677-684

36. Chen Z, Lu S, Mao Q, Buekens A, Chang W, Wang X (2016) Suppressing heavy metal leaching through ball milling of fly ash. Energies 9:1-13

37. Park YJ (2009) Stabilization of a chlorine-rich fly ash by colloidal silica solution. J Hazard Mater 162:819-822

38. Zheng L, Wang W, Shi Y (2010) Chemosphere the effects of alkaline dosage and $\mathrm{Si} / \mathrm{Al}$ ratio on the immobilization of heavy metals in municipal solid waste incineration fly ash-based geopolymer. Chemosphere 79:665-671

39. Tang J, Steenari B (2016) Leaching optimization of municipal solid waste incineration ash for resource recovery: a case study of $\mathrm{Cu}, \mathrm{Zn}, \mathrm{Pb}$ and $\mathrm{Cd}$. Waste Manag 48:315-322
40. Song GJ, Kim KH, Seo YC, Kim SC (2004) Characteristics of ashes from different locations at the MSW incinerator equipped with various air pollution control devices. Waste Manag 24:99-106

41. Hamernik J, Frantz G (1991) Physical and chemical properties of municipal solid waste fly ash.pdf. ACI Mater J 88:294-301

42. Jayaranjan MLD, van Hullebusch ED, Annachhatre AP (2014) Reuse options for coal fired power plant bottom ash and fly ash. Rev Environ Sci Biotechnol 13:467-486

43. Du B, Li J, Fang W, Liu Y, Yu S, Li Y, Liu J (2018) Characterization of naturally aged cement-solidified MSWI fly ash. Waste Manag 80:101-111

44. Galan I, Glasser FP, Andrade C (2013) Calcium carbonate decomposition. J Therm Anal Calorim 111:1197-1202

45. Wieczorek-ciurowa K, Paulik J, Paulik F (1980) Influence of foreign materials upon the thermal decomposition of dolomite, calcite and magnesite part I. Influence of sodium chloride. Thermochim Acta 38:157-164

46. Pedersen AJ, Ottosen LM, Villumsen A (2003) Electrodialytic removal of heavy metals from different fly ashes: influence of heavy metal speciation in the ashes. J Hazard Mater 100:65-78

47. Miljøministeriet Bekendtgørelse om anvendelse af restprodukter og jord til bygge- og anlægsarbejder og om anvendelse af sorteret, uforurenet bygge- og anlægsaffald; 2010; Vol. 2010, pp $1-15$

48. Dunn KG (2014) Latent Variable Modelling. In: Dunn KG (ed) Process improvement using data. pp 325-416

49. Paine K (2019) Physicochemical and mechanical properties of Portland cement. In: Hewlett P, Liska M (eds) Lea's chemistry of cement and concrete. Butterworth-Heinemann, Oxford, pp 285-332

50. Mindess S (2019) Resistance of concrete to destructive agencies. In: Hewlett P, Liska M (eds) Lea's chemistry of cement and concrete. Butterworth-Heinemann, Oxford, pp 251-283

51. De Weerdt K, Kjellsen KO, Sellevold E, Justnes H (2011) Synergy between fly ash and limestone powder in ternary cements. Cem Concr Compos 33:30-38

52. DS/EN 206 DK NA (2018) Beton - Specifikation, egenskaber, produktion og overensstemmelse-Regler for anvendelse af EN 206 i Danmark; Dansk Standard

53. Kurdowski W (2002) Chloride corrosion in cementitious system. In: Bensted J, Barnes P (eds) Structure and performance of cements. Taylor \& Francis, New York, pp 295-310

54. Bertolini L, Carsana M, Cassago D, Curzio AQ, Collepardi M (2004) MSWI ashes as mineral additions in concrete. Cem Concr Res 34:1899-1906

55. Lee TC, Wang WJ, Shih PY (2008) Slag-cement mortar made with cement and slag vitrified from MSWI fly-ash/scrubber-ash and glass frit. Constr Build Mater 22:1914-1921

56. Belmonte LJ, Ottosen LM, Kirkelund GM, Jensen PE, Vestbø AP (2018) Screening of heavy metal containing waste types for use as raw material in Arctic clay-based bricks. Environ Sci Pollut Res 25:32831-32843

57. Chen Z, Lu S, Tang M, Ding J, Buekens A, Yang J, Qiu Q, Yan J (2019) Mechanical activation of fly ash from MSWI for utilization in cementitious materials. Waste Manag 88:182-190

Publisher's Note Springer Nature remains neutral with regard to jurisdictional claims in published maps and institutional affiliations. 